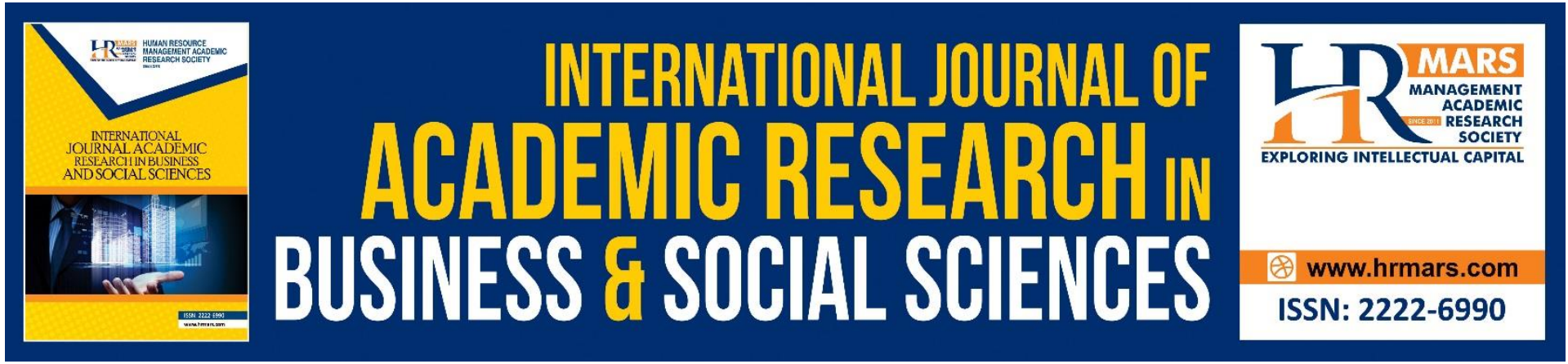

\title{
Identity Struggle between the Orient and the Occident in Tayeb Salih's Season of Migration to the North. A Postcolonial Rendering
}

Isyaku Hassan, Hamzeh Ali Najadat, Mohd Nazri Latiff Azmi, Habibu Awais Abubakar, Mubarak Ibrahim Lawan

To Link this Article: http://dx.doi.org/10.6007/IJARBSS/v11-i7/10382

DOI:10.6007/IJARBSS/v11-i7/10382

Received: 20 May 2021, Revised: 22 June 2021, Accepted: 09 July 2021

Published Online: 25 July 2021

In-Text Citation: (Hassan et al., 2021)

To Cite this Article: Hassan, I., Najadat, H. A., Azmi, M. N. L., Abubakar, H. A., \& Lawan, M. I. (2021). Identity Struggle between the Orient and the Occident in Tayeb Salih's Season of Migration to the North: A Postcolonial Rendering. International Journal of Academic Research in Business and Social Sciences, 11(7), 1155-1165.

\section{Copyright: (C) 2021 The Author(s)}

Published by Human Resource Management Academic Research Society (www.hrmars.com)

This article is published under the Creative Commons Attribution (CC BY 4.0) license. Anyone may reproduce, distribute, translate and create derivative works of this article (for both commercial and non-commercial purposes), subject to full attribution to the original publication and authors. The full terms of this license may be seen at: http://creativecommons.org/licences/by/4.0/legalcode

Vol. 11, No. 7, 2021, Pg. 1155 - 1165

Full Terms \& Conditions of access and use can be found at http://hrmars.com/index.php/pages/detail/publication-ethics 


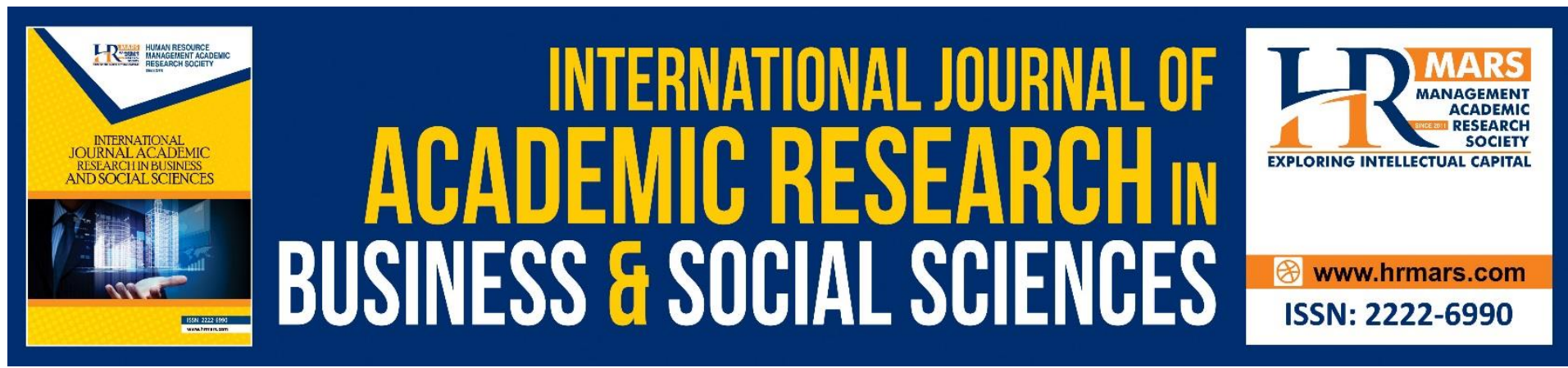

\title{
Identity Struggle between the Orient and the Occident in Tayeb Salih's Season of Migration to the North. A Postcolonial Rendering
}

\author{
Isyaku Hassan, Hamzeh Ali Najadat, Mohd Nazri Latiff Azmi \\ Faculty of Languages and Communication Universiti Sultan Zainal Abidin, Terengganu, \\ Malaysia \\ Email: najadath@gmail.com
}

Habibu Awais Abubakar

Kano State College of Education and Preliminary Studies Kano, Nigeria

\section{Mubarak Ibrahim Lawan}

Department of English and Literary Studies AI-Qalam University Katsina, Nigeria

\begin{abstract}
Identity becomes one of the most debatable and controversial issues in most postcolonial communities. This paper highlights the problematic issue of identity struggles in Tayeb Salih's Season of Migration to the North using critical postcolonial theory. The paper argues that Salih uses imagery and symbolism techniques as a way of "writing back" and resisting European control. The issue of identity in the narrative is represented as unstable, unbalanced, and oscillating between the two cultures. Salih reflects his personal conflict of losing and keeping identity through characters, which simulates reality. The analysis shows how the Europeans influence the Easterners' cultural identity as well as the middle point between the Orient and the Occident. This influence from the colonizer creates a situation of identity struggle in the colonized society, which creates a complex environment with many ramifications in determining their true identity. This study concludes that the oriental/occidental identity struggle still exists and will continue to exist as long as the West keeps its dominance over the East.
\end{abstract}

Keywords: Colonial Dominance, Identity, Post-colonialism, Orient, Occident, Tayeb Salih

\section{Introduction}

Tayeb Salih was a writer of the 20th-century born and raised in Sudan (Stampfl, 2009). He was a prominent figure among Arab writers owning to his hybrid cultural identity - oriental western. Salih studied at the University of Khartoum, and then moved to and settled in London in 1952. This helped Salih to increase his creativity in writing and thinking. He got married to a Scotland woman, Julia. This marriage was considered a distinguished part of his 
life. His lifestyle can be considered as a denial of the concept of cultural sincerity and determined identity because he lived with double languages as well as a hybrid identity.

Salih spent twelve years as the head of BBC's Arabic Service, followed by other several jobs in the Radio Committee of Khartoum. Salih also worked for a couple of years in the Qatar Ministry of Information and the United Nations Educational, Scientific, and Cultural Organization (UNESCO) (Salih, 2009). Salih's experiences and hybrid identity are exhibited in his literary works (Stampfl, 2009). Salih spent most of his lifetime in England and died there in the colonizer's land, although he was living between England and Sudan (Elad, 2007).

The outburst of postcolonial literature is one of the most prominent exciting features of English literature written in previously colonized societies (Ashcroft, Griffiths, \& Tiffin, 2003). It is an area of research interest with a variety of theoretical thoughts, notions, predicaments, and debates evident in various research articles, essays, and books across the world (Ashcroft et al., 2003). There had been a colonial presence in the Arab world since the collapse of the Ottoman Empire until the Arab countries such as Sudan, Egypt, Jordan, Syria, and Morocco got their independence after World War II (Ferro, 2005). As a result, various literary works including Tayeb Salih's Season of Migration to the North have been produced, employing characters that resisted colonization through their identities.

Identity is defined as "an abiding sense of the self and the relationship of the self to the world" Northrup (1989, p. 55). Identity simply becomes a problem in a crisis - when issues have to be fixed (Shore, 1996). In the postcolonial environment, identity is a complex concept that is difficult to define (Dizayi, 2015). Identity crisis exists in all postcolonial societies and is considered one of the most debatable and controversial issues in the postcolonial period. This problem occurs because the colonized nations struggle for their cultural identity and social formation of newly independent nations. Each nation tries to explore and reshape selfidentity while rejecting features of the colonizer, and therefore the crisis of identity floated on the surface (Gunew, 1997).

A thoughtful reading of Tayeb Salih's novel reveals the oriental/occident gap with various complex narrative structures and massive rely on flashbacks. The novel deals with the influence of European colonization on the colonized natives and lands. It also reflected upon how the cultural identity of the colonized countries is absorbed into the universal colonial center. This study aims to explore the identity struggle between the Orient and the Occident in Tayeb Salih's Season of Migration to the North. This analysis could advance our understanding of the issue of an identity crisis, particularly in Salih's novel due to its suitability to the context of this study in both author and text approaches. Salih lived in two different oriental periods of colonization and postcolonialism and experienced two different cultures of both East and West in Sudan and Britain respectively.

\section{Identity in Postcolonial Period}

The issue of identity is not a precise and framed concept as it can be an imagined and converted phenomenon. Identity simply converts to an issue when it is in crisis and when events that are supposed to be fixed, consistent, and firm, relocated by the experience of ambiguity and uncertainty (Shore, 1996). Thus, when one lives in a different home that does not belong to him, such a person will feel unstable. Sarup (1994) confirms this meaning in Home and Identity, stating that home provides security, identity, a place where one is comfortable and where stability, warmth, comfort, relaxation, and meaning prevail. For this reason, most people who live outside of their homelands try to stabilize their identities and 
remove possible barriers. In this sense, Schulz and Hammer (2003) describe identity as "diasporic searches for identity" when it becomes an issue that provokes new boundaries.

The quest for identity is, perhaps, the most significant theme that has a dominant presence in the Arabic postcolonial literary texts. It had its roots in the discourse of the Nahda (the Arab Renaissance) when the Arab intellectuals reflected on their cultural instance in comparison with Europe. There is no doubt that during the struggle for independence, Arab intellectuals were also driven by an overwhelming desire to define themselves concerning others (Al-Musawi, 2003). The influence of occidental imperialism on the oriental identity is strong indeed. Thus, postcolonial identity, after the independence and decolonization of the oriental states, becomes unstable and oscillating as well as changes continually because of idiosyncrasies of the identity culturally, economically, and politically.

Another key point that is associated with postcolonial identity is "modernism" which was characterized by the colonial education system that has been imposed on the colonized countries. In this regard, Kelly and Altbach (1978) illustrate that colonial education was designed primarily to serve the interests of the colonizing powers. Therefore, the colonial education system has a tremendous influence on indigenous identities, especially through language, culture, and religion. Under these factors, the issue concerning identity has been continuously raised. Culture is one of the elements that play an essential role in determining and shaping one's identity. In Salih's Season of Migration to the North, the cultural differences are taken seriously in matters concerning identity.

\section{Critical Scholarship on Season of Migration to the North}

A number of studies explored different issues in Salih's Season of Migration to the North using various literary approaches, such as psychoanalysis theory and postcolonial theory (e.g. Maqdisi, 1992; Elewa, 2002; El Khairat, 2008; Karkaba, 2010; Alhawamdeh, 2013; Adam, 2015; Zeidanin, 2016; Draweesh, 2019). Most of these studies focus on the interpretation of the novel's protagonist, Mustafa Sa'eed, and how this character is represented. For instance, Adam (2015) analyzed the main character in Salih's novel through a psychoanalytic lens in terms of a mixed-race relationship. The study focused on Mustafa Sa'eed's personality in Sudan and London, particularly his relationships with oriental and western women. According to the analysis, the interracial relationship by Mustafa "is used as revenge and punishment for the Europeans for their crime of African exploitation" (p. 101). Some studies highlighted the cultural struggle between the east and the West through Mustapha Sa'eed and other main characters such as the unnamed narrator in Salih's novel (Geesey, 1997; El Khairat, 2008; Velez, 2010; Hughes, 2011; Zeidanin, 2016). The studies demonstrated how the main characters reacted to the traditions and modernity of Sudan during and after the British presence.

According to Hughes (2011), the main characters in Season of Migration to the North demonstrate "how colonial power dismantled and transformed modes of identification as such, leaving deeper chasms in how people experienced life and community" (p. 1). Zeidanin (2016) argues that "Saeed is neither a nationalist nor assimilationist; rather, he is a culturally hybrid character who equally identifies with the occidental culture of England and the oriental culture of Sudan" (p. 76). Sa'eed is irresolute to find his "home' since London at one time is envisioned as his 'home' and, at other times, is the land of 'Imperialism' (Velez, 2010). According to Dizayi (2015), the crisis of identity in Season of Migration to the North is "related to the imperial power legacy by revealing the idea of otherness" (p. 1002). This struggle for identity is considered to be a continuous process (Karkaba, 2010). 
According to Zeidanin (2016), the conflict between the narrator and Saeed in Tayyib Salih's novel "emanates from psychological and ideological sources and foreshadows their relations with the western civilization and women" (p. 76). While they develop discordant attitudes towards the west, they unconsciously consider it as an ally whose ideas, skills, and sciences should be copied and transmitted. Salih's novel is used as a tool of resistance and "writing back" for the colonial presence in Sudan, specifically, and the Arab world in general (Maqdisi, 1992; El Khairat, 2008). The novel reinvents and reclaims the history of the African Sudanese people from the colonized's point of view (Alhawamdeh, 2013). Draweesh (2019) found that the two main places (London and the Sudanese village) directly affect the discourse strategy in Salih's novel. The novel draws people's attention to the complex historical and cultural relationships between the Arab/African world and Western Europe. Similarly, Geesey (1997) concludes that Season of Migration to the North presents a message of "bicultural, or cultural, grafting as an antidote to the 'germ' of cultural contagion that may be a negative byproduct of European colonial endeavors in Africa" (p. 139).

Previous studies on Season of Migration to the North focused on various issues such as European colonialism (Hamadi, 2014), identity crisis (Hughes, 2011), immigration (Dizayi, 2015), political identities (Elewa, 2002), diaspora, exile, alienation and searching for a homeland (Canlı, 2004), deconstruction of identity (Karkaba, 2010), orientalism discourse (Alhawamdeh, 2013), cultural hybridity (Adam, 2015; Geesey, 1997), traditions and the modernity of Sudan (El Khairat, 2008), resistance "writing back" (Maqdisi, 1992; El Khairat, 2008), politeness and ideology (Draweesh, 2019), as well as psychology and ideology (Zeidanin, 2016).

The previous studies adopted either a psychoanalytic approach (eg. Zeidanin, 2016; Adam, 2015) or postcolonial theory (eg. Hamadi, 2014; Elewa, 2002; Karkaba, 2010; Alhawamdeh, 2013). The studies also touch upon issues such as immigration, political identities, diaspora, exile, alienation, deconstruction of identity, identity crisis, and cultural struggle either during the colonial period or in the post-colonial period. None of the previous studies focused specifically on the struggle of identity between the Orient and the Occident specifically in Salih's Season of Migration to the North. However, the current study pays particular attention to the issue of identity through postcolonial theory concerning the Orient and the Occident.

\section{Method}

This study utilized an eclectic approach that combines two important approaches to textual analysis: author-oriented approach and context-oriented approach. The author-oriented approach demonstrates a direct link between the literary text and the biography of the author while the context-oriented approach extends to the social, historical, and political aspects (Klarer, 2004). According to McKee (2003), different methods produce different sorts of answers depending on how the information is gathered. This is because the text itself has codes and implied messages which could be used to interpret reality and obtain a sense of the ways where people make sense of the world around them (McKee, 2003).

The audience has to bear in mind that words have different denotations and connotations and each statement has two probable truth values: true or false. This study aims to analyze Salih's Season of Migration to the North through a postcolonial lens concerning the identities of two major characters - the unnamed narrator and Mustafa Sa'eed. Some literary devices are used to serve the desired themes, focusing primarily on characterization, settings, flashbacks, and imagery. A good procedure to grasp the themes in the novel is to relate the 
text to its historical and cultural settings since the author is part of the history and culture that surrounded him. In this study, the analysis of identity struggles between the Orients and the Occident is guided by postcolonial theory.

\section{Synopsis of Season of Migration to the North}

The translated novel Season of Migration to the North achieved glorious success among the eastern and western literary critics. It is considered one of the best novels of its time as stated by Hassan in the preface of the novel (Salih, 2009). The novel is a representation of the political view of the conflict between the two cultures (Friedman, 2006). The issue of identity is constructed as a consequence of cultural conflicts between western and eastern societies. In the plot, Mustafa Sa'eed and the narrator himself are comparable with each other (AbuHaydar, 1985).

After studying for seven years in England, the narrator decides to return to his small native village in Sudan. The narrator finds it easy to recognize almost everyone because the village is very small. However, he could not recognize a nearly 50 -year old man, and this person attracts the narrator's attention. Later, the narrator knows that the strange person is Mustafa Sa'eed, who arrives five years ago to settle in Wad Hamid village. Mustafa lives in a house near the Nile River with one wife and two sons. It appears that Mustafa is happy with the respect and admiration which he receives from the villagers (Salih, 2009).

The narrator was so interested in Mustafa's personality and started to question his past and true story especially when Mustafa recited a piece of poetry during an evening party in fluent English. According to the narrator, Mustafa was in England for study purposes. He started his education at Khartoum elementary school and then moved to Cairo for his secondary school education. At the age of 24, Mustafa became a lecturer of economics at the University of London. During his stay in London that lasted about 30 years, Mustafa had connections with many Englishwomen. He attempted to seduce them and eventually caused them to commit suicide. Mustafa was imprisoned for his last seven years in London for killing his English wife - Jean Morris.

The feeling of diaspora and the conflict of keeping and losing identity appear sharply in the novel through Mustafa's relations with the West. His inner world was morally and spiritually distorted and damaged. Though Mustafa still adopts the European culture, he broke the chain to blend with such culture, and at the same time, he disinherited his origins and roots (Hassan, 2003). Mustafa, as a migrant, was in a dilemma that he could not settle in the West or in his homeland where he felt isolated. People in the village dealt with him as a stranger or a person from another world. It is a matter of peace of mind because Mustafa lives in misery as he becomes lost between two different worlds.

\section{Identity Struggle between the Orient and the Occident}

The quest for identity is, perhaps, the most significant theme that has a dominant presence in the Arabic novel. There is no doubt that during the struggle for independence, Arab intellectuals were also driven by an overwhelming desire to define themselves in relation to others (Al-Musawi, 2003). The influence of imperialism on the oriental identity is strong indeed. Thus, postcolonial identity, after the decolonization of the oriental states, becomes unstable. In Salih's Season of Migration to the North, the cultural differences led to an identity crisis. The colonizer mocks Mustafa Sa'eed's wearing of a turban “This isn't a turban, he said. It's a hat.... When you grow up, the man said, and leave school and become an official in the government, you'll wear a hat like this" (p. 20). In this context, Salih laments the displacement 
of the Islamic "turban" with the colonizer's "hat".

One of the central themes in postcolonialism is "writing back", i.e. a form of resistance through the novel genre (Widdowson, 2006; Thieme, 2001). Salih's Season of Migration to the North describes the pressure of western culture on the colonized countries as the destruction of the Sudanese culture. In the novel, Salih shows that the British culture clashes with the Sudanese culture specifically and the Oriental culture generally. Mustafa Sa'eed's interracial relationships can be interpreted as an opposing discourse between the Arab and British cultures. In his relationships, Mustafa implores the application of colonial discourse to preserve the colonial categorizations. By doing so, he classified his lovers as a portion of the harsh West. Mustafa's refusal of his European lovers can be described as a metaphorical denial of the West.

Upon landing in his country, the unnamed narrator's extraordinary love for his country became obvious. Although the unnamed narrator "learnt much and much" (Salih, p. 1) about western culture and traditions, he would not discuss it then, since he needs to grab the chance to express love for his people. He feels so glad to live once more in his homeland "after a long absence of seven years during his study period in Europe" (p. 1). When the unnamed narrator was in Europe, he "longed for them [the villagers], had dreamed of them, and it was an extraordinary moment when [he] at last found [him] self-standing amongst them" (p. 14). His life out there is different - a place where there is the colonizer, "a land whose fishes die of the cold" (p. 14). He appreciates the "life warmth of the tribe" (p. 14) and "felt not like a storm-swept feather but like that palm tree, a being with background, with roots, with a purpose" (p. 14).

The above description shows that the narrator is still mindful of the positive side of tribal and village life; a helpful and steady life that is loaded with warmth, ease, and simplicity. The narrator found that despite everything, his dad still recites the Quran and practices his supplications. Moreover, his mom still serves the family and gets the tea to them in the mornings. On the second day of his return to his village, he notices that "yes, life is good and the world as unchanged as ever" (p. 15).

Mustafa Sa'eed, whose experience is similar to the narrator's, lived for quite a while in Britain for study purposes and experienced the European culture. The narrator starts to notice that this unfamiliar person carries with him the standards of western innovation and radicalism, which completely oppose the villagers' values. When the narrator tries to reveal that the Europeans are, to a large extent, just like the orientals, Mustafa Sa'eed was calm and speechless. Here, the narrator conveys a message to people in the East, especially the youth, that Europeans are just like us. They have good and bad in their community like us - "over there is like here, neither better nor worse" (49).

Mustafa Sa'eed keeps quiet because he knows the reality of what the narrator says. Mustafa has a better knowledge of western life than the narrator but has a different view of the Europeans. He refused to say everything concerning Europeans, though he wishes he had done it because he was afraid to be misunderstood especially by his companion - Mahjoub (p. 16). Mahjoub is clever but would not see why the colonizers are just normal individuals like them, though they imposed on him a culture that does not suit his community and religion. They assaulted his country and misrepresented the Arab image to legitimate their colonial project.

Some Arabs think deeply about the negative impact of the conventions that consider anyone who dislikes them as "heathen", as Bint Majzoub echoed the narrator, saying "we were afraid, you'd bring back with you an uncircumcised infidel for a wife" (p. 16). Suha 
Kudsieh clarifies the problem of those intellectuals, who were once taught in Europe, such as the narrator, Mustafa Sa'eed, and even Tayeb Salih himself. They returned home outfitted with the best instructive testaments and education. They carry with them the significance of the instructive European fortunes, just to get themselves defenseless in the general public. Moreover, "they live under the burden of the conventions and the myths, rather than battling back, they surrendered under the heaviness of customs and got to be distinctly latent and dormant" (Kudsieh, 2003, p. 210). The narrator's grandfather is a symbol of the humble and simple life before the occupation of Sudan - life without any complexities, difficulties, or problems. All complexities and challenges of life are brought by the colonizers. He could say that his grandfather is "something immutable in a dynamic world" (p. 50).

When Mustafa narrates his life in Britain, the narrator felt the differences between the two cultures (western and eastern cultures). The narrator was so depressed and afraid, meaning that Mustafa's stories threaten his hope of a steady life free from colonialism. Once the narrator "reached the door of [his] grandfather" and listened to his "voice praying" ( $p$. 50), he became feels exultant. However, when he returns to his community; he does not try to change the common bad habits in his village, since every community has good and bad manners. Tayeb Salih used the foreshadowing technique to give the readers a hint of what will happen. Although the narrator heard about the story of a "woman from the tribe of ElMirisab [who] had killed her husband and the government was in the process of arresting her" (pp. 98-99), he did not try to stop her marriage.

The story progresses slowly to achieve the moment of its necessary parts: setting, characterization, climax, and resolution. Hybridity plays a prominent role in the structure of the major characters in Season of Migration to the North, to the extent that Mustafa Sa'eed was given a new name - "the black Englishman" (Salih, p. 54). Mustafa behaves like the colonizers "while [he] had a sort of feeling of superiority towards them ... and [he], over and above everything else, [is] a colonizer (p. 87). The variation between Occidental and Oriental cultures characterizes the presence of hybridity (Bhabha, 2012). Mustafa Sa'eed is described as "a dark twilight like false dawn" (Salih, p. 36).

Another revisited scene of the novel is when the narrator comes back to his homeland and talks to his readers as part of the audience "gentlemen, after a long absence, [1] returned to [my] people" (p. 14). This scene indicates that the narrator has a feeling of fear of the pollution and infection of the cultural hybridity. This is because the western culture affects his identity, as clarified by Geesey (1997) that "he [the narrator] attempts to reassure himself that his years of living in England have not shaken his singular and well-rooted sense of identity" ( $p, 130)$. Nevertheless, Mustafa Sa'eed's attitude toward his mother could reflect his colonized spirit, misplaced identity, and admiration for the West. As portrayed in the novel, Mustafa describes his mother as a vague woman with many masks and Mrs. Robinson as a great woman with a great European smell. This situation describes the rejection of the "Self" (inferior) and the longing for the "Other" (superior), as well as being lost in the hybrid world. Mustafa Sa'eed tries to satisfy English society that he is one of them, but he remains a person of a lower position amongst them. His wife, Jean Morris, always disgrace him because of his identity and tells him "[you are] ugly" (p. 36) and, at times, they tell him "[we have] never seen an uglier face than [yours]" (p. 36).

\section{Conclusion}

This study used postcolonial theory to highlight the issue of the oriental/occidental identity struggle in Salih's Season of Migration to the North. The analysis has mainly demonstrated 
the search for identity which appears to be a continuous and unbalanced relationship between the Orient and the Occident. The Occident depicts the Orient in their novels as people who need to be civilized and liberated. On the other hand, some of the oriental diasporic intellectuals, such as Tayeb Salih, try to resist and respond to the western hegemony through the method of "writing back". Tayeb Salih describes the issue of identity as unstable, unbalanced, and oscillating between the two cultures. Under these circumstances, the East and the West can never meet up. The colonizer's influence creates a situation of identity struggle in the colonized society, which in turn, creates a complex environment with many ramifications in determining their true identity.

The contribution of this study lies in its provision of empirical evidence and logical analysis of how the Europeans influence non-western cultural identity, particularly in Season of Migration to the North, from a postcolonial perspective. The analysis could advance our knowledge of how postcolonial writers employ imagery and symbolism techniques as a way of "writing back" and resisting European control. There is vast literature on Salih's Season of Migration to the North. However, this study is limited to how the author represents the subject of identity struggle between the Orient and the Occident. Further research may draw a comparison of postcolonial novels, including Season of Migration to the North, on the notion of identity struggle between the Orient and the Occident.

\section{References}

Abu-Haydar, J. (1985). A novel difficult to categorize. In M. T. Amyuni (ed), A Casebook (pp. 15-36). Beirut: American University Press.

Adam, A. A. S. (2015). A revenge endeavour (And) unconscious desire: Psychoanalytic study on Mustafa Saeed in Tayeb Salih's Season of Migration to the North. European Journal of English Language and Literature Studies, 3(4): 95-102.

Alhawamdeh, H. (2013). The different western perceptions of the oriental Moor in the renaissance and the twentieth century: Shakespeare's Othello and Tayeb Salih's Season of Migration to the North: A post-Colonial critique. Transnational Literature, 5(2), 1-11.

Al-Musawi, M. J. (2003). The postcolonial Arabic novel: Debating ambivalence. Leiden: Brill.

Ashcroft, B., Griffiths, G., \& Tiffin, H. (2003). The empire writes back: Theory and practice in post-colonial literature. London: Routledge.

Bhabha, H. K. (2012). The location of culture. London: Routledge.

Banerjee, S. B., \& Linstead, S. (2001). Globalization, multiculturalism and other fictions: colonialism for the new millennium. Organization, 8(4), 683-722.doi: $10.1177 / 135050840184006$

Canlı, G. (2004). Postcolonial novel: Quest for home. Journal of Arts and Sciences, 2(2), 1-11.

Dizayi, S. A. H. (2015). The crisis of identity in post-colonial novel, In 2nd International Conference on Education and Social Sciences, Proceedings of INTCESS15, (2015). Istanbul, Turkey: Istanbul Aydin University.

El Khairat, A. (2008). Narrating the empire: Nationalism, memory and gender in Arab postcolonial novel, the case of Tayyib Salleh's Season of Migration to The North, Mohammed Berrada's the Game of Forgetting and Assia Djebar's L'Amour, la Fantasia (Unpublished Master's thesis). Utrecht University, Utrecht, Netherlands.

Elad, A. (2007). Voices of exiles: A Study of Al-Ṭayib Șāliḥ and his work (Vol. 22). London: Oxford University Press. 
Elewa, S. A. (2002). In search of the other/self: colonial and postcolonial narratives and identities. (Unpublished Master's thesis). University of Hong Kong, Pokfulam, Hong Kong.

Ferro, M. (2005). Colonization: A global history. London: Routledge.

Friedman, S. S. (2006). Periodizing modernism: Postcolonial modernities and space/time borders of modernist studies. Modernism/modernity, 13(3), 425-443.

Geesey, P. (1997). Cultural hybridity and contamination in Tayeb Salih's" Mawsim al-hijra ila al-Shamal (Season of Migration to the North). African Literatures, 28(3), 128-140.

Gunew, S. (1997). Postcolonialism and multiculturalism: Between race and ethnicity. In the YEARBOOK of English Studies (pp. 22-39). Colombia: University of British Colombia.

Gupta, S. D. (2007). Imperialism and colonialism: towards a postcolonial understanding. Science, Technology, Imperialism, and War, (pp. 423-466). Delhi, India: Pearson Education.

Hamadi, L. (2014). Edward Said: The postcolonial theory and the literature of decolonization. European Scientific Journal Vol (2), 36-46.

Hassan, W. S. (2003). Tayeb Salih: Ideology and the Craft of Fiction. New York, NY, USA: Syracuse University Press.

Karkaba, C. (2010). Deconstructing identity in postcolonial fiction. Elope; English Language Overseas Perspectives and Enquiries, 7(2), 91-99.doi: 10.4312/elope.7.2.91-99

Kelly, G., \& Altbach, P. (1978). Introduction. In P. Altbach \& G. Kelly (Eds.), Education and colonialism (pp. 1-49). New York: Longman.

Klarer, M. (2004). An introduction to literary studies. London \& New York: Routledge.

Kudsieh, S. (2003). 'Season of Migration to the North: (Be)longing, (Re)location, and Gendered Geographies in Modern Arabic Travel Narratives'. Thamyris/Intersecting: Place, Sex and Race, 10 (1), 201-217. doi: 10.1163/9789004333468_012

Makaryk, I. R. (1993). Encyclopedia of contemporary literary theory: approaches, scholars, terms. Toronto, Ontario: University of Toronto Press.

Makdisi, S. S. (1992). The empire renarrated: Season of Migration to the North and the reinvention of the present. Critical Inquiry, 18(4), 804-820.

McKee, A. (2003). Textual analysis: A beginner's guide. London, Thousand Oaks and New Delhi: Sage Publications Ltd.

Northrup, T. A. (1989). The dynamic of identity in personal and social conflict. In L. Kriesberg, T. A. Northrup, \& J. T. Stuart (eds). Intractable conflicts and their transformation (pp. 55-82). Syracuse: Syracuse University Press.

Papastergiadis, N. (2013). The turbulence of migration: globalization, deterritorialization and hybridity. Oxford, England: John Wiley \& Sons.

Prasad, A. (2003b). 'The gaze of the other: Postcolonial theory and organizational analysis'. In Postcolonial theory and organizational analysis: A critical engagement (pp. 3-43). New York. NY: Palgrave Macmillan US.

Salih, T. (2009). Season of migration to the north. New York, NY: New York Review Books Classics.

Shands, K. W. (2008). Neither East nor West: Postcolonial Essays on Literature, Culture and Religion. Huddinge. Retrieved from http://urn.kb.se/resolve?urn =urn:nbn:se:sh:di

Shome, R., \& Radha S. H. (2002). Postcolonial approaches to communication: Charting the terrain, engaging the intersections. Communication Theory, 12(3), 249-270. doi: 10.1111/j.1468-2885.2002.tb00269.x 
Shore, C. (1996). Ethnicity, xenophobia and the boundaries of Europe. International journal on minority and group rights, 4(3), 247-262. doi: 10.1163/15718119620907319

Stampfl, T. (2009). (Im)possible encounters, possible (Mis)understandings between the West and Its other: The case of the Maghreb (Doctoral Dissertation). Louisiana State University.

Thakur, G. B. (2016). Postcolonial theory and Avatar: Bloomsbury Publishing USA. The White Review, (2014). Retrieved January 23, 2017.

Thieme, J. (2001). Postcolonial con-texts: Writing back to the canon. London: Bloomsbury Publishing.

Widdowson, P. (2006). 'Writing back': contemporary re-visionary fiction. Textual Practice, 20(3), 491-507. doi:10.1080/09502360600828984

Zeidanin, H. H. (2016). Psychological and cultural borderlands in Tayyib Salih's Season of Migration to the North. Advances in Language and Literary Studies, 7(1), 75-79.

Draweesh, Y. Y. (2019). Politeness and Ideology in Al Tayyeb Salih's Season of Migration to the North: A Critical Pragmatic Study. Master's thesis, English Department, Hebron University. Accessed: September 6 2020. Available:

http://dspace.hebron.edu/xmlui/handle/123456789/787

Hughes, M. A. (2011). Representations of identity in three modern Arabic novels. Colonial Academic Alliance Undergraduate Research Journal, 2(5), 1-31.

Velez, M. (2010). On borderline between shores: Space and place in Season of Migration to the North. College Literature, 37(1), 190-203. 